\title{
Middle Jurassic ankylosaur tracks from Mexico
}

\author{
Rubén A. Rodríguez-de la Rosa, María Patricia Velasco-de León, Javier Arellano-Gil,
} Diego Enrique Lozano-Carmona

Rubén A. Rodríguez-de la Rosa

ruben_raptor@yahoo.com

Unidad Académica de Ciencias Biológicas, Unidad Académica de Ciencias de la Tierra, Universidad Autónoma de Zacatecas, Campus II, Calzada Solidaridad, esq. Paseo de la Bufa s/n, C.P. 98060, Zacatecas, Mexico.

\section{María Patricia Velasco-de León Diego Enrique Lozano-Garmona}

Facultad de Estudios Superiores Zaragoza, Universidad Nacional Autónoma de México, Campus II, Batalla 5 de mayo s/n esquina Fuerte de Loreto, Ejército de Oriente, Iztapalapa, C.P. 09230, CDMX, Mexico.

\section{Javier Arellano-Gil}

Facultad de Ingeniería, Universidad Nacional Autónoma de México, Av. Universidad 3000, Ciudad Universitaria, Coyoacán C.P. 04510 , CDMX, Mexico.

BOL. SOC. GEOL. MEX. 2018

VOL. 70 NO. 2

P. $379-395$

http://dx.doi.org/10.18268/BSGM2018v70n2a8

Manuscript received: March 21, 2017. Corrected manuscript received: July 19, 2017. Manuscript accepted: September 29, 2017.

\section{ABSTRACT}

A track-bearing locality in one of the shore of the Numí River, near the City of Tlaxiaco, northwestern Oaxaca, southern Mexico, preserves the footprints of sauropod and theropod dinosaurs; it is located within the stratigraphic sequence of the Zorrillo-Taberna Indiferenciadas Formation, of Middle Jurassic (Bajocian) age. A well-preserved manus-pes set of ankylosaurian affinity (Tetrapodosaurus) is preserved on a rock block from this formation. These tracks are preserved as convex hyporeliefs. The pes impression is tetradactyl, with ventrally curved toe tips, suggesting that these were deeply impressed in the sediment. Manus impression is pentadactyl, with short and blunt digits. A curved structure preserved together with these footprints is herein interpreted to be a tail drag. The stratigraphic unit from whence this block came was identified and two additional ankylosaurian tracks, were found preserved in situ as natural sandstone casts. An isolated handprint, has the same features that fit the ankylosaurian hand morphology; however, some features such as a medio-lateral concavity are indicative of the presence of a well-developed palmar pad, and could suggest the functional mechanics of the ankylosaurian manus. The Zorrillo-Taberna Indiferenciadas Formation is a coal-bearing formation; after the global record, ankylosaur footprints are concentrated in coal-bearing and floodplain facies, thus suggesting, that at least the North American Ankylosauria were adapted to similar paleoecological conditions from Middle Jurassic to Early Cretaceous times. It represents the second report of ankylosaurian tracks from Mexico and the southernmost record of the ichnogenus Tetrapodosaurus in North America. In this way, it suggests a geographic continuum in the record of the Ankylosauria to southern North America during Middle Jurassic times. With their Middle Jurassic age, these footprints represent the oldest ankylosaurian ichnofossils known to date.

Keywords: Ankylosauria, Tetra podosaurus, Ichnology, Middle Jurassic, Oaxaca, Mexico.

\section{RESUMEN}

Una localidad icnofosilifera en una de las orillas del Río Ñmi en las cercanías de la Ciudad de Tlaxiaco, noroeste de Oaxaca, al sur de México, conserva las huellas de dinosaurios saurópodos y terópodos; esta se localiza dentro de la secuencia estratigráfica de la Formación Zorrillo-Taberna Indiferenciadas, de edad Jurásico Medio (Bajociano). Se identificó un conjunto de pie-mano de afinidad anquilosauriana (Tetrapodosaurus) en un bloque de roca procedente de esta formación; las huellas se encuentran conservadas como hiporrelieves convexos. El pie es tetradáctilo, con las puntas de los dedos curvadas ventralmente, sugiriendo que éstas fueron impresas profundamente en el sedimento. La mano es pentadáctila, con dedos pequeños y romos. Una estructura curvada, conservada junto a las huellas, es interpretada aquí como un arrastre de cola. El estrato original de procedencia del bloque portador de las huellas, fue identificado $y$ dos huellas adicionales de anquilosaurios fueron encontradas in situ, conservadas como rellenos naturales de arenisca. Un relleno natural de una mano fue encontrado de forma aislada; éste presenta los mismos caracteres morfológicos de la mano anquilosauriana; sin embargo, algunas características como la concavidad medio lateral de la zona palmar indica la presencia de un cojinete, y podría sugerir la mecánica funcional de la mano anquilosauriana. La Formación Zorrillo-Taberna Indiferenciadas es una formación con estratos de carbón; en otras secuencias sedimentarias las huellas de anquilosaurios se concentran en facies aluviales y portadoras de carbón, esto sugiere que al menos los Ankylosauria norteamericanos estaban adaptados a condiciones paleoecológicas similares, desde el Jurásico Medio al Cretácico Temprano. Este trabajo representa el segundo reporte de huellas de anquilosaurios en México, y el más sureño del icnogénero Tetrapodosaurus en Norte América; sugiriendo un continuum geográfico en el registro de Ankylosauria, hasta el sur de Norte América durante el furásico Medio. Además, son los icnofósiles más antiguos de anquilosaurios conocidos hasta este momento.

Palabras clave: Ankylosauria, Tetrapodosaurus, Icnología, Jurá sico Medio, Oaxaca, México. 


\section{Introduction}

During paleontological fieldwork in search for paleobotanical sites, one of the authors (MPVL) found a locality bearing dinosaur footprints in the Numí River, near the City of Tlaxiaco, northwestern Oaxaca, in southern Mexico (figures 1, 2). The locality preserves the footprints of sauropod and theropod dinosaurs (figures 3, 4) (Lozano-Carmona, 2012; Rodríguez-de la Rosa, 2014, 2015; Rodríguez-de la Rosa et al., 2014); it is located within the stratigraphic sequence of the Zorrillo-Taberna Indiferenciadas Formation, of Middle Jurassic age (Carrasco-Ramírez, 1981; González-Torres, 1989; Corro-Ortiz and Ruíz-González, 2011). This geological formation preserves a notable record of fossil plants of Bennettitales, Caytoniales, Equisetales, Filicales, conifers and Ginkgoales (Silva-Pineda et al., 2007; Lozano-Carmona, 2012; Velasco-de León et al., 2013; Velasco-de León et al., 2015; Lozano-Carmona and Velasco-de León, 2016). The study of this dinosaur tracksite started in a consecutive field season; however, it was noted that a fallen rock block in front of the main track-bearing surface (Figure 4) contained dinosaur tracks, preserved as natural casts in its underside. Among these tracks is a well-preserved manus-pes set of an ankylosaurian dinosaur.

Ankylosaurian remains have been collected in Mexico, mainly from northern states such as Baja California, Chihuahua and Coahuila. Among the most common ankylosaur remains found in Mexico are teeth and osteoderms, an isolated vertebra, and a few limb elements have also been found (Rivera-Sylva and Espinosa-Chávez, 2006; Rivera-Sylva et al., 2011; Martínez-Díaz and Montellano-Ballesteros, 2011). Kappus et al. (2011) mentions the presence of ankylosaur tracks near Ciudad Juárez, Chihuahua, northern Mexico. However, these authors present only illustrated outline drawings of the tracks, and do not specify which one of the illustrated specimens was found in Mexico, or if the specimen is available or lost as other specimens mentioned in their work. Furthermore, the ankylosaur tracks are referred to as
"Ankylosauripus" and/or "Tetrapodosauripus" (Kappus et al., 2011: 281), when both names are inexistent. Therefore, the purpose of this paper is to report these tracks, noting that due to their Middle Jurassic age, they represent the oldest ankylosaurian ichnofossils known to date.

\section{Geological setting}

The study area is located in the Tlaxiaco Basin, which is placed in the boundary between the Zapoteco and Mixteco terrains (Dávalos-Álvarez, 2006); both terrains in contact along the Caltepec lateral fault (Sedlock et al., 1993). The late Aalenian (early Middle Jurassic) Numí Conglomerate (or Cualac Conglomerate) is the oldest unit within the local stratigraphic column (Corro-Ortiz and Ruíz-González, 2011). The Tecocoyunca Group is a very fossiliferous rich unit overlying the Numí Conglomerate, with an age that ranges from the Bajocian to Callovian (Erben, 1956; Sandoval and Westermann, 1986; Lozano-Carmona and Velasco-de León, 2016). According to Carrasco-Ramírez (1981) the Tecocoyunca Group is composed of four formations that, in ascending stratigraphic order are, the Zorrillo-Taberna Indiferanciadas Formation, Simón, Otatera, and Yucuñuti formations. Subsequently, González-Torres (1989) divided the Tecocoyunca Group into two subgroups: a lower unit comprising the Zorrillo-Taberna Indiferenciadas and Simón formations, and an upper unit comprising the Otatera and Yucuñuti formations (Figure 5). The youngest Jurassic unit outcropping in the area corresponds to a marine environment unit named Caliza con Cidaris (Cidaris-bearing limestone) of Oxfordian age (Carrasco-Ramírez, 1981). The only post-Jurassic formation outcropping in the area is the Albian-Cenomanian Teposcolula Formation of marine origin, composed of carbonate platform limestones (Pérez-Ibargüengoitia et al., 1965).

The rock block containing the ankylosaurian footprints belongs to the Zorrillo-Taberna Indiferen- 


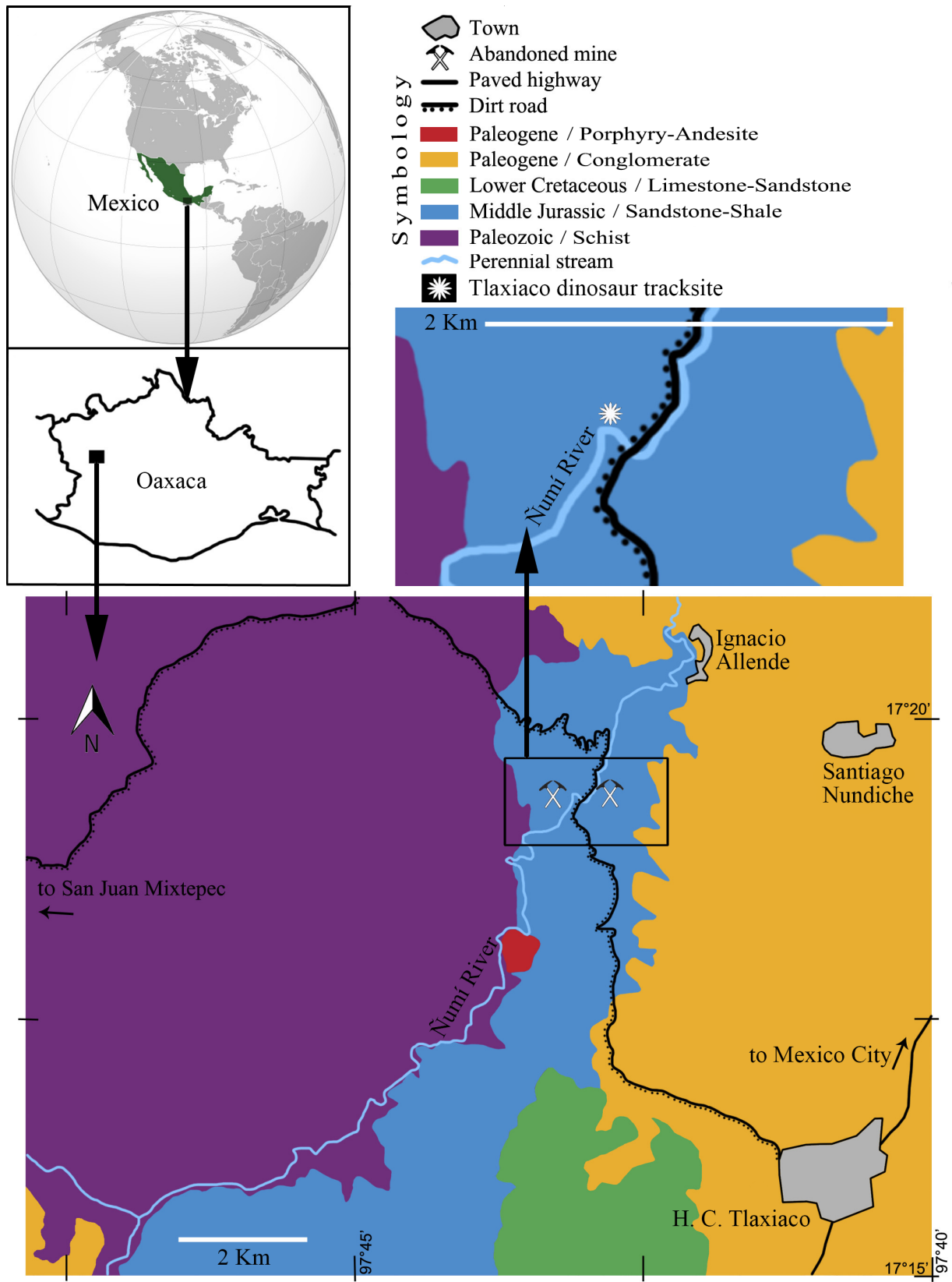

Figure 1 Regional map and geographic location of the Tlaxiaco tracksite (white asterisk), near the Ñumí River, northwest from the City of Tlaxiaco, western Oaxaca, southern Mexico.

ciadas Formation of Middle Jurassic (Bajocian) age. This age was determined due to its content of the ammonites: Duashnoceras Westermann, Leptosphinctes Buckman and Parastrenoceras Ochoterena from the Taberna Formation (Sandoval and Westermann, 1986). The Zorrillo-Taberna Indiferenciadas Formation is a succession of sandstones (subarkoses, litharenites and graywackes), shale, and thin coal beds. The shale layers are tabular-shaped and $10-40 \mathrm{~cm}$ in thickness; the sandstone layers are irregular and discontinuous with a thickness of $20-70 \mathrm{~cm}$. In the case of the ankylosaurian tracks, these are preserved as natural casts or convex hyporeliefs in a sandstone layer, while the tracks and/or concave epireliefs were originally registered in a shale layer. 


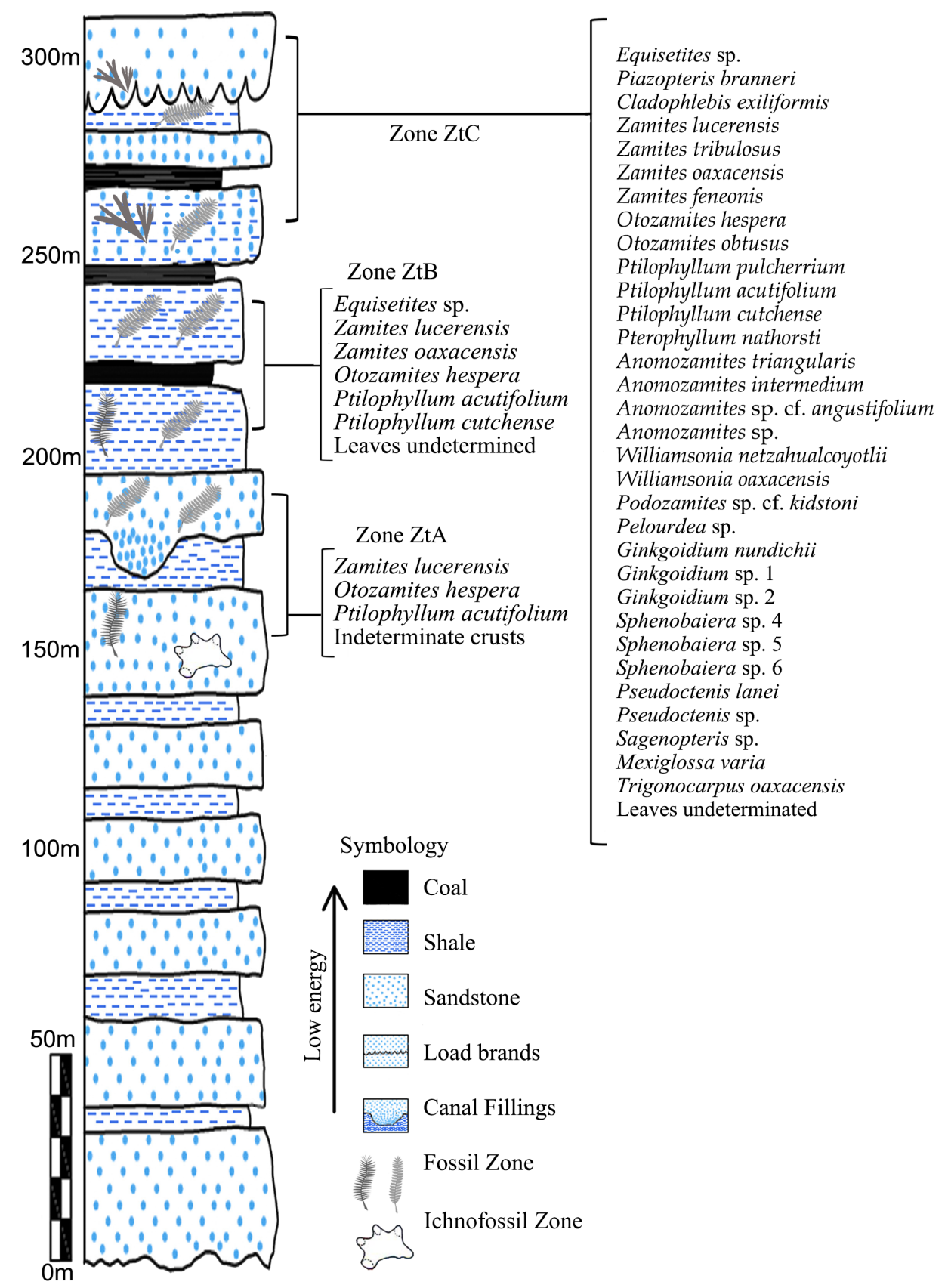

Figure 2 Stratigraphic column near Ñumí River, at 150 - 190 m footprints are indicated.

\section{Material and methods}

The outline of the ankylosaurian tracks was drawn on a plastic sheet using waterproof ink markers; additionally, silicon rubber molds and resin casts of the ankylosaur footprints were made. These, and other materials, are now housed at the Paleontological Collection of the Facultad de Estudios Superiores Zaragoza, Universidad Nacional Autónoma de México under the catalogue numbers: CFZ-Zt 305, ankylosaur manus and pes; and CFZ-Zt 306, an ankylosaur manus natural sand- 


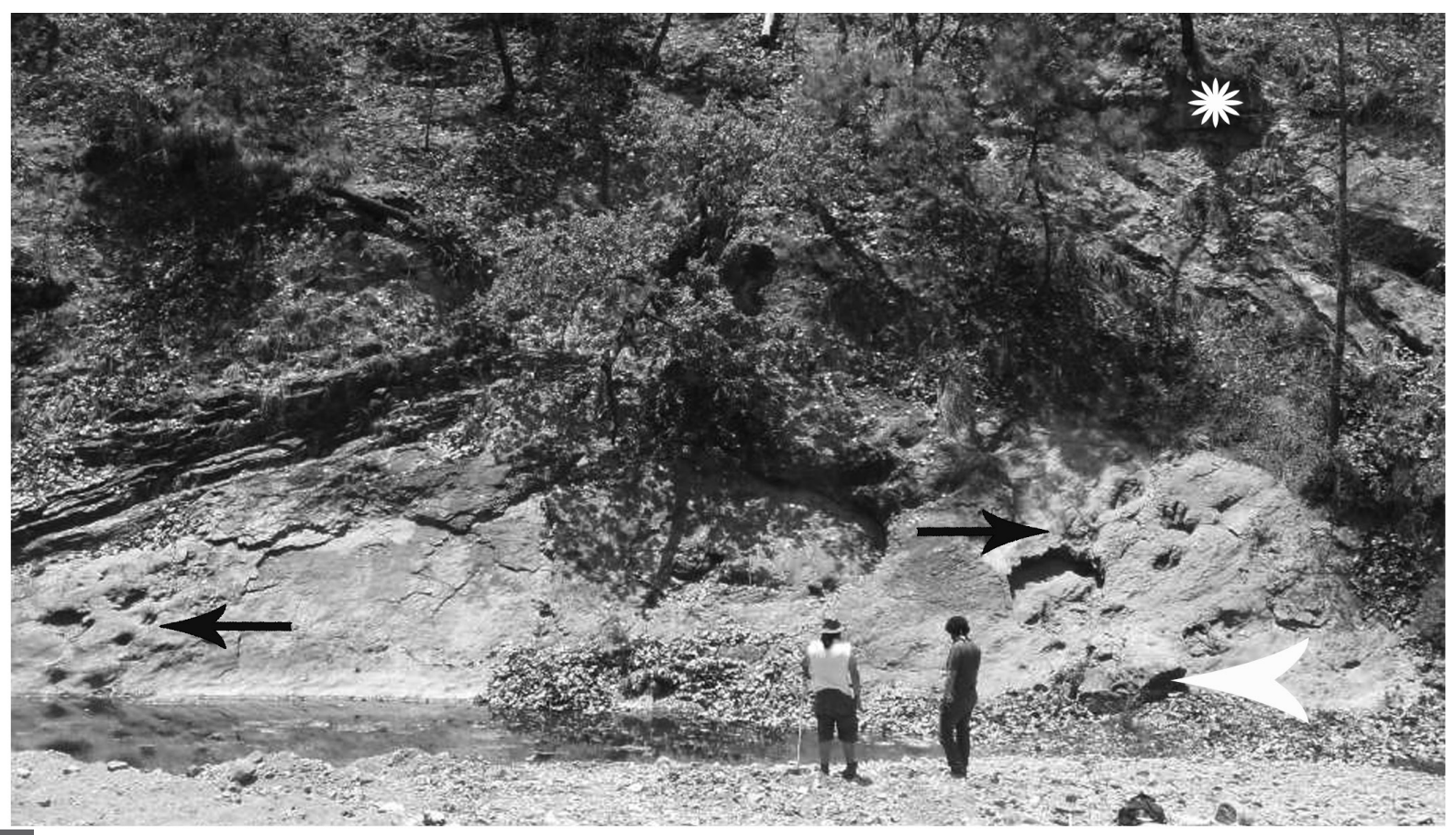

Figure 3 General view of the Tlaxiaco tracksite. Black arrows point to the two different footprint concentrations. To the left, badlypreserved footprints, these were left in a water-saturated sediment; to the right, well-preserved footprints of sauropod and theropod dinosaurs. The white arrowhead points to the rock block with the ankylosaur footprints. The site of provenance of this block is marked with the white asterisk.

stone cast. Measurements of the tracks were taken using standard metric tapes, a Vernier caliper and a conventional protractor.

\section{Results}

Systematic ichnology

Ichnofamily Tetrapodosauridae Sternberg, 1932

Ichnogenus Tetrapodosaurus Sternberg, 1932

Tetrapodosaurus isp.

(Figure 6)

\subsection{MATERIAL}

The fallen rock block bears at least three ankylosaurian tracks preserved as natural casts (convex hyporeliefs), as well as plant leaves (Figure $6 \mathrm{~A}, \mathrm{~B})$. In the case of the ankylosaurian tracks, a manus-pes set and a partial pes were recognized (Figure 6C); the block is composed of fine-grained sandstone; however, as mentioned above, the tracks were originally preserved in a carbonaceous shale layer. The catalogue codes are CFZ-Zt 305 for the ankylosaur manus and pes, and CFZ-Zt 306 for the ankylosaur manus natural sandstone cast.

\subsection{DESGRIPTION}

Pes impression is tetradactyl (Figure 6C); this impression presents a well-defined rounded heel, short and stout digits I and II, digits III, and IV slightly elongated, with faintly acuminated tips; these are curved and show an outward orientation. Additionally, digits III and IV preserve ventrally curved toe tips, suggesting that these were deeper impressed in the sediment. Pes impression measures $33 \mathrm{~cm}$ in maximum antero-posterior length and $26 \mathrm{~cm}$ in maximum medio-lateral width. The interdigital angles are of $22^{\circ}$ for digits I - II, $41.5^{\circ}$ for digits II - III, and of $25.5^{\circ}$ for digits III - IV; thus, the digit total divarication is of $89^{\circ}$ (digits IIV). The distance between the toe tips is $9 \mathrm{~cm}$ for 

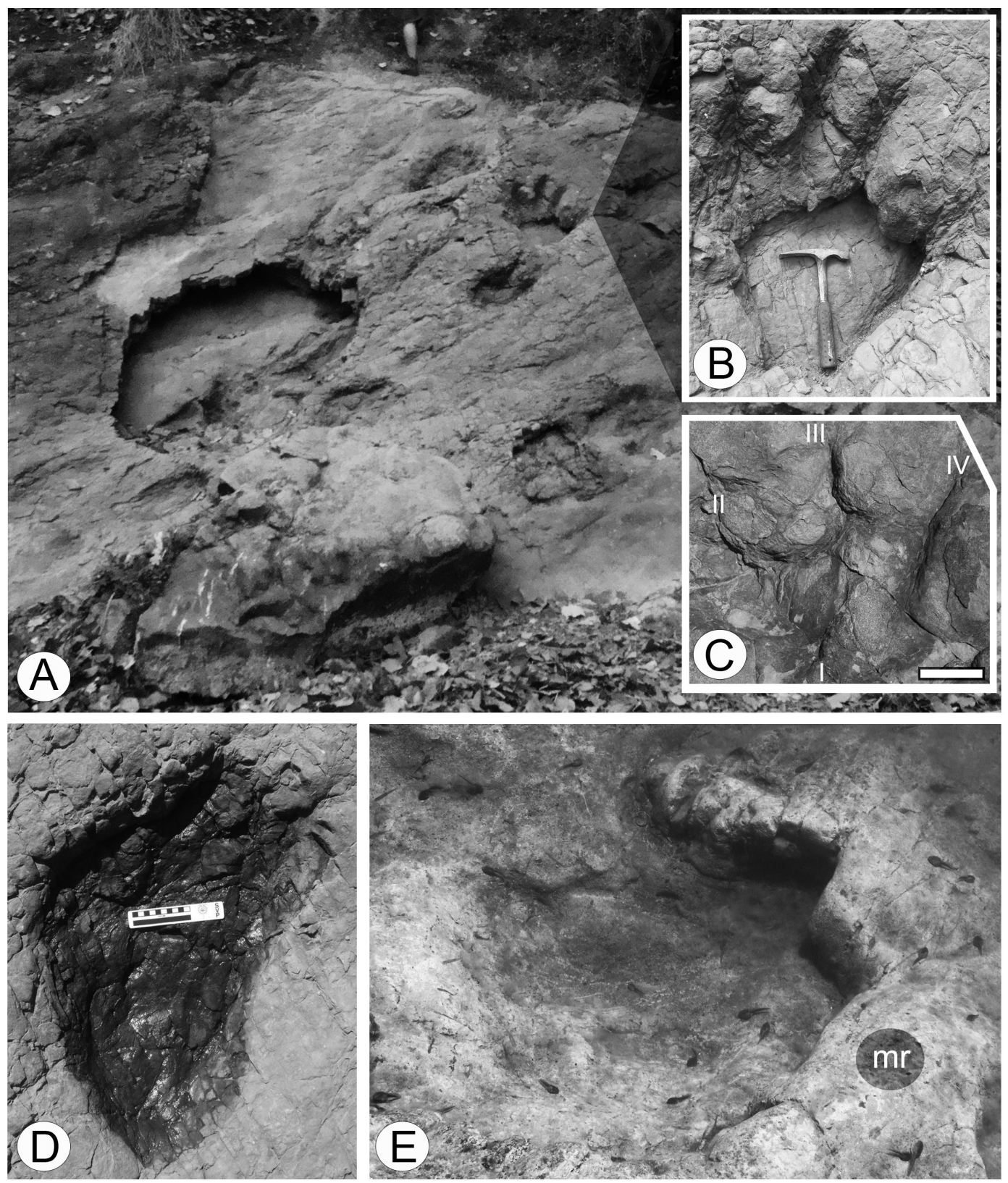

Figure 4 Dinosaur footprints at the Tlaxiaco tracksite. A. General view of the outcrop; B. Sauropod footprint, partially overstepped by a large theropod; C. Collapsed theropod footprint, note the hallux impression (I), and digits II to IV; D. Sauropod footprint, with digits rotated to the right; E. Sauropod footprint, this footprint is not in direct association with the ones above mentioned, instead it was discovered under the water of Numí River, note the well-defined claws, mudrim (mr) and tadpoles that arrive to the footprint after it was cleaned. Hammer for scale in B, the scale in C and D equals $10 \mathrm{~cm}$.

digits I - II, $17.5 \mathrm{~cm}$ for digits II - III, and 10.2 $\mathrm{cm}$ for digits III - IV. The anterior portion of a second pes impression is preserved in one of the block ridges, thus it is possible that it forms a single step, $63.5 \mathrm{~cm}$ in length, with the pes impression previously described (Figure 6C).
Manus impression is pentadactyl and fits the outline of a rough pentagon (Figure 6C); it is clear that a manual pad is present; it is wider than long, being $21 \mathrm{~cm}$ and $16 \mathrm{~cm}$, respectively; digit $\mathrm{V}$ is observed as a small bump located posterolaterally, while the other digits are short and blunt (Figure 
$6 \mathrm{C})$. The angles between digits is $55.5^{\circ}$ between digits I - II, $33^{\circ}$ between digits II - III, $55.5^{\circ}$ between digits III $-\mathrm{IV}$, and $55^{\circ}$ between digits $\mathrm{I}-\mathrm{V}$. Thus, the digit total divarication is $199^{\circ}$ (digits I $-\mathrm{V}$ ).

A curved structure is preserved together with these footprints. It is slightly elongate, forming an arch, with an acute posterior end and a wider anterior portion; it is here presumed to be a tail drag (Figure $6 \mathrm{~A})$.

\subsection{COMMENTS}

In spite of these tracks representing a manus-pes set, the manus track represents a right one and pes track represents a left one (Figure 7G). It implies that the manus-pes set belongs to a single individual organism and/or that the footprints had a distribution due to a particular mode of locomotion. A third possibility is that these tracks represent overstepping of two individuals traveling in the same direction.

The original level containing the ankylosaurian tracks was identified through petrographic slides through the track-bearing rock block and associated rock layer (Figure 3), both being litarenite. In addition to this, two other ankylosaurian tracks were identified in situ (Figure 8). These are preserved as natural sandstone casts; although weathered, it is possible to note one hand impression (Figure 8).

Additionally, an isolated sandstone cast of a hand was found, as an eroded footprint-bearing layer (Figure 7). This natural cast presents the same morphological features as the hand impression described above; it suggests the presence of a palmar pad in these ankylosaur tracks, in having small and rounded digital impressions (Figure 7A, B). It is wider than long, being $26.3 \mathrm{~cm}$ and $16 \mathrm{~cm}$, respectively; digit $\mathrm{V}$ is observed as a small bump located posterolaterally, while the other digits are short and blunt (Figure 7A, B; compare with Figure $6 \mathrm{C}$ ). The angles between digits is $55^{\circ}$ between digits I - II, $42^{\circ}$ between digits II - III, $30^{\circ}$ between digits III $-\mathrm{IV}$, and $58^{\circ}$ between digits IV - V. Thus, the total digit divarication is $185^{\circ}$ (dig- its $\mathrm{I}-\mathrm{V}$ ). An additional interesting feature of this natural cast is that it preserves a palmar surface with a medium-lateral concavity (Figure 7C); suggesting that the original footprint was not homogeneously impressed in the sediment; this feature is, perhaps, indicative of the functional mechanics of the ankylosaurian manus (Figure 7C, D). Small patches of faint skin impressions are preserved in some areas of this hand natural cast (Figure 7E). A photograph of the palmar view of the nodosaurid Edmontonia hand was digitally superimposed to this cast, the fit was remarkable (Figure 7D).

\section{Discussion}

\subsection{PRODUGER OF THE TRAGKS}

The Tlaxiaco tracks contain obvious features such as tetradactyl pes and pentadactyl manus; the general features of these tracks allow the comparison with those of ankylosaurs and ceratopsians (McCrea et al., 2001). McCrea et al. (2001), refer to some morphological criteria that help to discriminate between ceratopsian and ankylosaur footprints. For this purpose, the authors compared the general morphology of two ichnogenera, Tetrapodosaurus and Ceratopsipes, which represent the tracks of ankylosaurs and ceratopsians, respectively (Carpenter, 1984; Lockley and Hunt, 1995; McCrea et al., 2001). Although Tetrapodosaurus and Ceratopsipes have a pentadactyl manus, it is small in proportion to the pes size in Ceratopsipes and larger in proportion to the pes size in Tetrapodosaurus (McCrea et al., 2001). One of the most conspicuous differences is that digits are better defined in Tetrapodosaurus than in Ceratopsipes (McCrea et al., 2001). The pes in both ichnogenera are tetradactyl; however, Ceratopsipes pes is roughly symmetrical in outline (Lockley and Hunt, 1995), it has shorter toe impressions (i.e., with more enclosing flesh), and the inner digit (digit I) is larger than in Tetrapodosaurus (McCrea et al., 2001). Tetrapodosaurs bears an asymmetrical pes and longer toe impressions (i.e., with less enclosing flesh) and a shorter inner digit or digit I (McCrea et al., 2001). Based on these features, the Tlaxiaco 


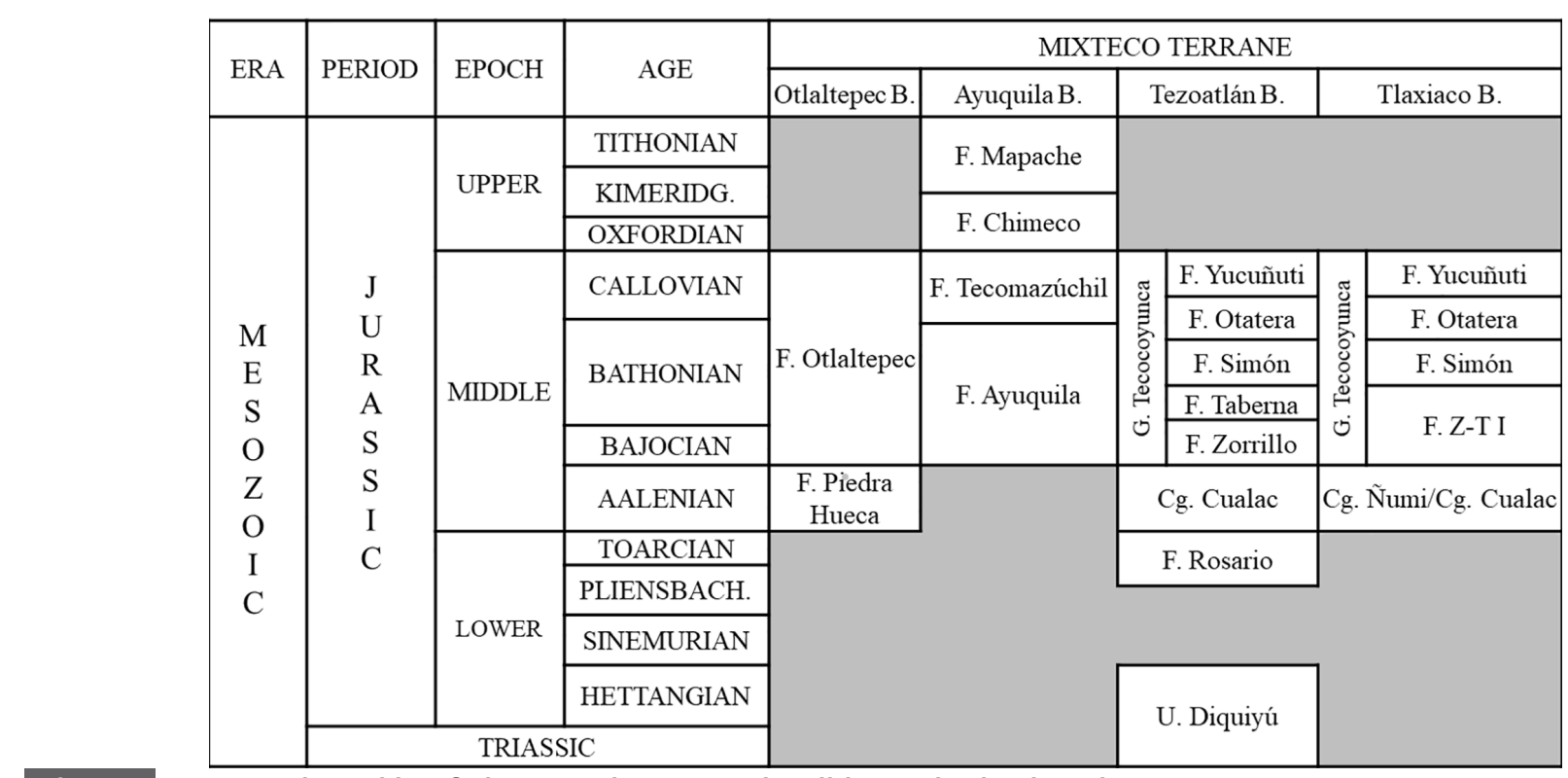

Figure 5 Comparative table of the Jurassic outcropping lithographs in the Mixteco Terrane. F. Z-T I, means Zorrillo-Taberna Indiferenciadas Formation.

tracks are undisputable, ankylosaurian in origin.

McCrea et al. (2001) reviewed the global record of ankylosaur tracks; these authors summarized the ichnogenera considered as produced from ankylosaurian dinosaurs and included Tetrapodosaurus Sternberg, 1932; Deltapodus Whyte and Romano, 1994; Macropodosaurus Zakharov, 1964; Metatetrapous Nopcsa, 1923, and Ligabueichnium Leonardi, 1984.

Initially, the ichnogenus Macropodosaurus was considered as produced from a theropod dinosaur (Zakharov, 1964); however, McGrea et al. (2001), based the similarity of the pes impressions and compared this ichnogenus to Metatetrapous, originally considered as produced by an ankylosaur by Haubold (1971). However, some authors still relate the ichnogenus Macropodosaurus to segnosaurian theropods (Sennikov, 2006).

Ligabueichnium, was established by Leonardi (1984) for a trackway from the El Molino Formation (Potosí Group), in Bolivia; the author suggested a possible relationship with a ceratopsid or an ankylosaur; however, in a subsequent work, he mentioned that "Ligabueichnium bolivianum may be attributed to an unusually large Ankylosauria" (Leonardi, 1994: 39) and it is now considered as ankylosaurian in origin by several authors (McCrea et al., 2001). In regard to Deltapodus, Whyte and Romano (1994) reported this ichnotaxon from the Middle Jurassic of Yorkshire, England; they interpreted it, as made by a sauropod dinosaur. Lockley et al. (1994) subsequently reinterpreted these tracks as produced by a thyreophoran dinosaur; currently, Deltapodus is widely considered as an ichnotaxon made by stegosaurian dinosaurs (e.g., Milàn and Chiappe, 2009; Mateus et al., 2011).

The ichnogenus Tetrapodosaurus was established by Sternberg (1932), based on a trackway found in sediments of the Lower Cretaceous Gething Formation in British Columbia, Canada. Although, it was initially interpreted as ceratopsian in origin, it is now attributed with confidence to nodosaurid ankylosaurs (McGrea et al., 2001). In addition to a tetradactyl pes with well-developed heel and pentadactyl manus, the general morphology of the Tlaxiaco tracks strongly resembles that of Tetrapodosaurus.

Regarding a possible ceratopsian origin for the Tlaxiaco tracks, it is necessary to mention that the earliest record of ceratopsians are teeth collected in late Early Cretaceous sediments of the Arundel and Cedar Mountain formations in U.S.A. (Chin- 

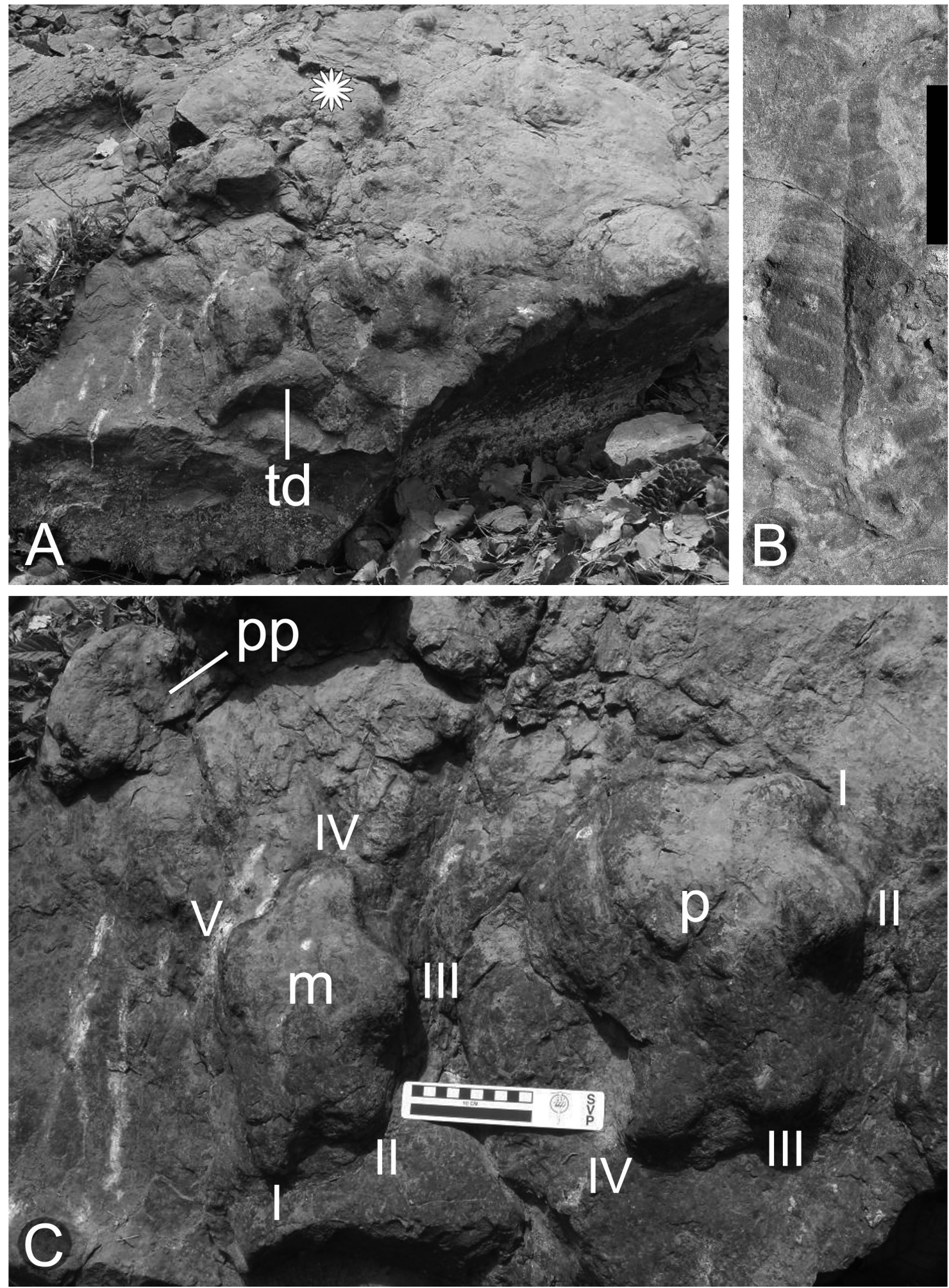

Figure 6 Ankylosaur footprints in the rock block. A. General view of the block, note the ankylosaur footprints (Tetrapodosaurus) at the center of the photograph and the supposed impression of a tail drag (td), the white asterisk is in the place of a well-preserved Zamites Iucerensis leaf detailed in B; C. Ankylosaur footprints (Tetrapodosaurus), note the pentadactyl manus ( $\mathrm{m}$, digits I- V) and the tetradactyl pes (p, digits I - IV). Note the ventrally impressed digits II to IV of the pes (p) and a partial pes (pp) at the upper-left of the photograph. Scale for B equals $2 \mathrm{~cm}$, scale in $\mathrm{C}$ equals $10 \mathrm{~cm}$. 


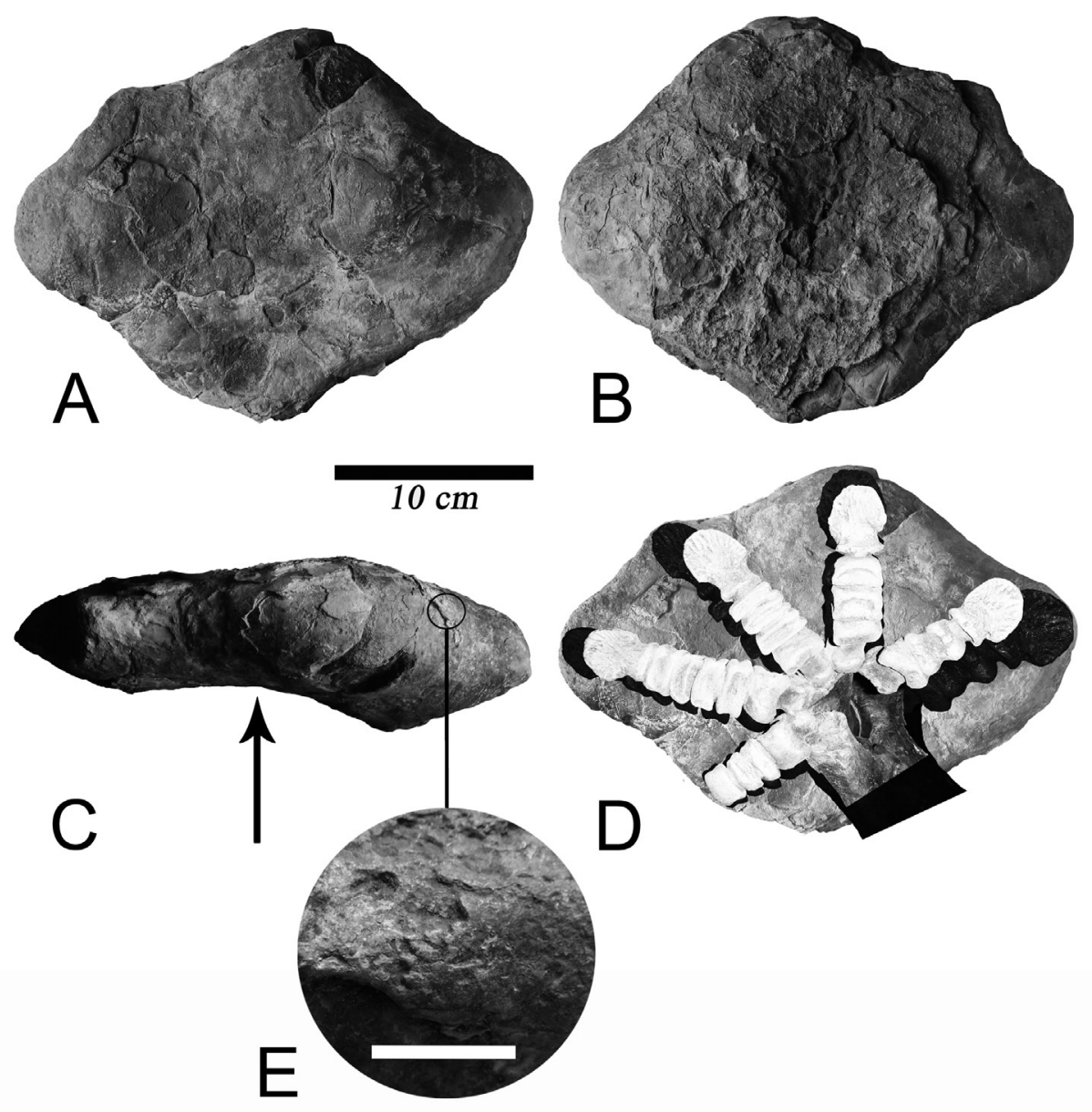

Figure 7 CFZ-Zt 306, Tetrapodosaurus manus. It is a right manus natural sandstone cast. A. Palmar view; B. Dorsal view; C. Distal view; D. Palmar view of sandstone cast and superimposed skeletal manus elements of the nodosaur Edmontonia (in white color), the black color ones are modified to fit the digit position as suggested by the natural cast; E. Possible skin impressions. Scale in E equals $1 \mathrm{~cm}$.

nery et al., 1998). However, the earliest record of large ceratopsians is known from Turonian deposits of Moreno Hill Formation in New Mexico (Wolfe and Kirkland, 1998). In this way, being of Middle Jurassic age, ceratopsians are discarded as the trackmakers of the Tlaxiaco tracks. Ankylosaurian dinosaurs are known to occur since the Middle Jurassic in Europe and Asia (Galton, 1983; Zhiming, 1993; Carpenter et al., 1998; Kirkland et al., 1998). In North America, the earliest record of ankylosaurs comes from the Late Jurassic Morrison Formation (Kirkland and Carpenter, 1994; Carpenter et al., 1998); in fact, the sediments of the Morrison Formation of Western Colorado have yielded the only ankylosaur track known from the Late Jurassic (Hups et al., 2008). This track resembles the manus of Tetrapodosaurus and has been illustrated by Lockley et al. (2014).

The Tlaxiaco ankylosaur pes preserves the toe tips, digits III and IV, in such a form that indicates these were deeply impressed in the sediment. A similar situation has been mentioned by McCrea et al. (2001); these authors noted that some Cenomanian Tetrapodosaurus tracks from the Dunvegan Formation of British Columbia, Canada, preserve deeply impressed tip digits, and were impressed in rather dried sediment. In addition, McCrea et al. (2001) mention two ankylosaur trackways, from 
the Maastrichtian El Molino Formation of Bolivia; where the trackways "seem to suggest that the tracks were perhaps made on an overlying layer of sediment and represent the penetration of the distal portion of the toes into an under layer" (Mc Crea et al., 2001: 442).

Findings from Canada and Bolivia together with the Tlaxiaco ankylosaur footprints, could yield insights into the mechanical function of the anklylosaur pes, at least suggesting a good subjection to the ground; perhaps for the use of the tail. Indeed, a similar condition could be suggested by the isolated natural cast of the hand from Tlaxiaco (Figure 7) that bears a well-developed palmar pad with a ventral medio-lateral concavity (Figure 7C). This suggests that the original footprint was not homogeneously impressed in the sediment; a feature suggesting, as well, part of the functional mechanics of the ankylosaurian manus. Some authors have suggested that a palmar pad is an unexpected feature for ankylosaurs (Senter, 2011); this based on track morphology of the hand impressions, as well as the ankylosaurian metacarpal configuration (Senter, 2011). However, the features of the three ankylosaur hand impressions from Tlaxiaco support the presence of a palmar pad.

Together with the tracks, a supposed tail drag is preserved; no tail impressions are known to occur associated to ankylosaur footprints. However, in regard to this, nodosaurid dinosaurs had a longer tail than that present in ankylosaurids (Carpenter, 1982, 1984). For example, the ankylosaurid Euoplocephalus had 21 caudal vertebrae; while it has been estimated 40 to 50 caudal vertebrae for nodosaurids, such as Sauropelta (Carpenter, 1982, 1984). It is thus possible that some nodosaurids left an occasional tail drag.

Most of the early members of Ankylosauria were small; forms such as Mymoorapelta and Gargoyleosaurus in North America, Tianchisaurus in Asia, and Cryptodraco and Dracopelta in Europe, were not longer than 3 m (Galton, 1983; Carpenter, 1984; Zhiming, 1993; Kirkland and Carpenter, 1994; Carpenter et al., 1998). However, the nodosaur Sauropelta, which has been regarded as the track- maker of the Tetrapodosaurus tracks (Carpenter, 1984; McCrea et al., 2001), was an organism with a calculated length and weight of approximately $5.2 \mathrm{~m}$ and $1500 \mathrm{~kg}$, respectively (Carpenter, 1984). When compared with the data raised from Sauropelta and Tetrapodosaurus footprint size (Carpenter, 1984; McCrea et al., 2001; Sternberg, 1932), the Tlaxiaco Tetrapodosaurus tracks suggest an organism ca. $3.8 \mathrm{~m}$ in length and nearly $1 \mathrm{t}$ in weight.

\subsection{PALEOENVIRONMENTAL GONDITIONS}

The plant macrofossils associated with the Tlaxiaco dinosaur footprints include Bennettitales, the most diverse order with 17 of the 34 species identified in the plant community; among these, Zamites lucerensis (Wieland) Person and Delevoryas, 1982 and Otozamites hespera Wieland, 1914, are abundant, while Anomozamites triangularis (Nathorst) Pott and McLoughlin, 2009; Anomozamites sp. cf. intermedium Antevs, 1919 as well as Zamites sp., are rather rare. Conifers are represented by Podozamites sp. cf. kidstonii Etheridge, in Jack and Etheridge, 1892. Mexiglossa varia Delevoryas and Person, 1975 and Trigonocarpus oaxacensis Wieland, 1914 are common and frequent respectively, however, both are of uncertain taxonomic position (Lozano-Carmona, 2012; Lozano-Carmona and Velasco-de León, 2016). The order Ginkgoales is represented by several new species within the genera Ginkgoidium and Sphenobaiera (Velasco-de León et al., 2015). Ferns are important herbaceous elements and, together with Equisetales, have been associated to a climate with humid seasons (Van Konijnenburg-Van Citter, 2002; Rojas-Chávez, 2010); while the genera of conifers identified in the Jurassic of Mexico have been associated to a warm climate (Person and Delevoryas, 1982). However, the presence of Ginkgoales and Coniferales in the study area suggests a rough mountain relief, temperate and mesic conditions, as well as little variations in the local climate (Rees et al., 2000; Wang et al., 2005; Zhou, 2009).

The identified flora bears a high percentage of small leaves; in this case, $72 \%$ of the identified plants had microphyl leaves with an area between 


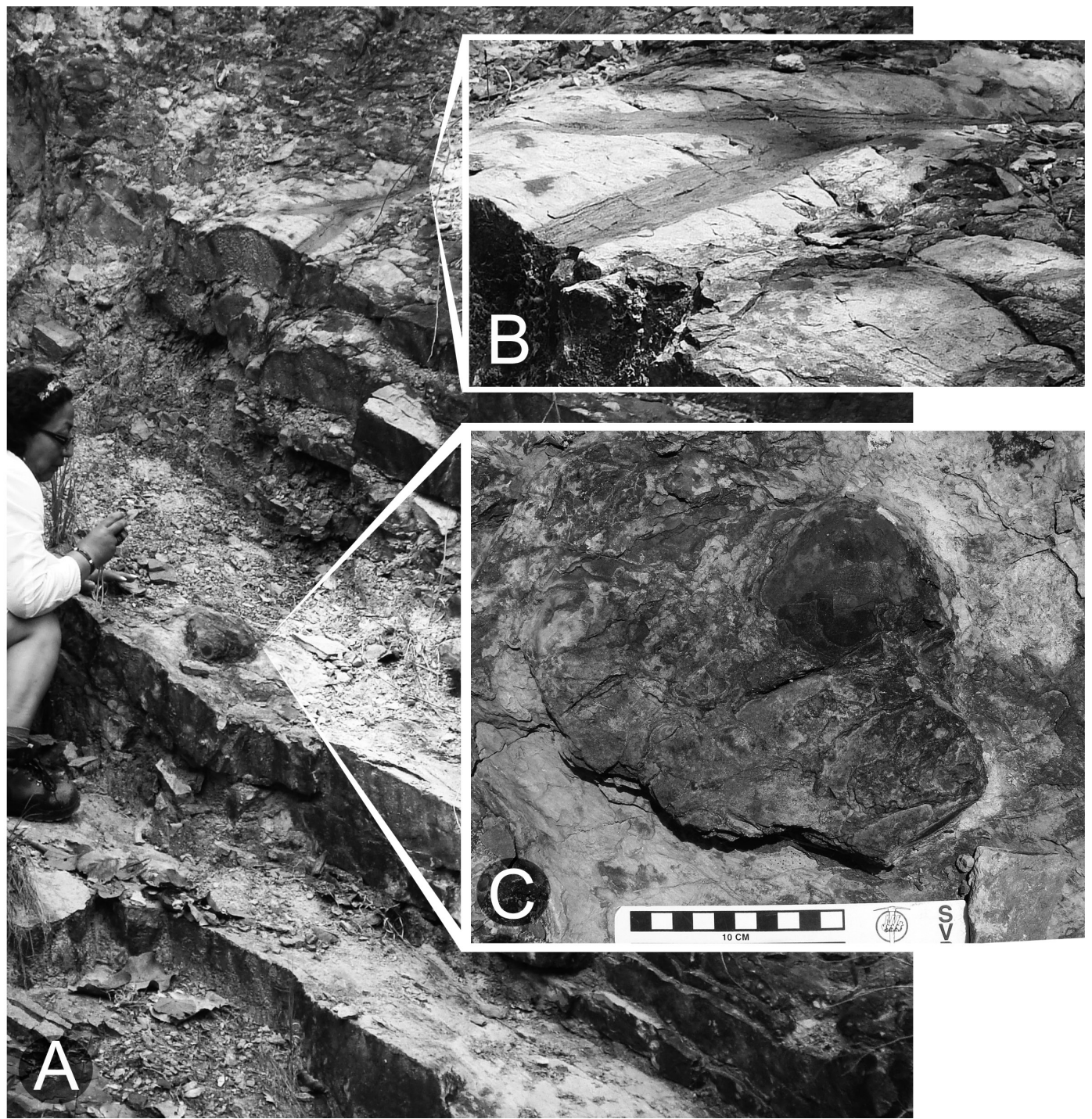

Figure 8 Location of provenance of the rock block bearing Tetrapodosaurus footprints. A. The site is marked with a white asterisk in Figure 3; B. Fossilized log; C. In situ manus sandstone cast in dorsal view (scale $10 \mathrm{~cm}$ ).

0.08241 to $1.3660 \mathrm{~cm}^{2}$ (Lozano-Carmona, 2012; microphyl 1 type sensu Ortiz-Martínez et al., 2013). This feature indicates the dominance of a subwarm, sub-humid climate, and with periods of low water circulation in the floodplain allowed the swamps establishment; these swamps accumulate a great amount of organic matter that formed the coal layers, $1.5 \mathrm{~m}$ thick, present in the Zorrillo-Taberna Indiferenciadas Formation. The paleobasin was subject to a continuous subsidence that permitted the homogeneous depositional and environmental conditions during its forma- tion (Corro-Ortiz and Ruíz-González, 2011). The plant remains preserved in the Zorrillo-Taberna Indiferenciadas Formation surely were part of the diet of the Middle Jurassic herbivorous dinosaur communities present at the Tlaxiaco area, included is the nodosaurid ankylosaur, represented by these Tetrapodosaurus tracks.

In regard to the paleoecological conditions, the Tlaxiaco nodosaurid ankylosaur tracks were found in a coal-bearing formation, such as the Zorrillo-Taberna Indiferenciadas Formation. This observation agrees with that of McCrea et al. (2001); 
these authors mention that ankylosaur footprints are concentrated in coal-bearing and floodplain facies. Also, ankylosaurs seem to have a preference for well-vegetated and well-watered lowlands (McCrea et al., 2001). This environmental condition is supported by the great amount of coal and plant remains found in the Zorrillo-Taberna Indiferenciadas Formation (Lozano-Carmona, 2012; Velasco-de Léon et al., 2013). Even more, well preserved Zamites lucerensis leaves were found preserved in the same surface of the Tetrapodosaurus footprints (Figure $6 \mathrm{~B})$.

The fact that the Tlaxiaco nodosaurid ankylosaur tracks are preserved in a coal-bearing formation, such as the Zorrillo-Taberna Indiferenciadas Formation, suggest that at least the North American Ankylosauria was adapted to similar paleoecological conditions since Middle Jurassic times.

\section{Conclusions}

The presence of Tetrapodosaurus tracks in the south of Mexico indicates the existence of a geographic continuum in the record of the Ankylosauria to southern North America during Middle Jurassic times. Also, these footprints represent the oldest ankylosaurian ichnofossils known to date. In this way, the ankylosaur diversity at the Middle Jurassic seems represented by at least two body sizes, small and medium, for these thyreophoran dinosaurs.

\section{Acknowledgements}

Authors want to thank to members of the April 2011 field season; also to Gerardo Reyes (Universidad Nacional Autónoma de México) for making the silicone rubber mold and the cast of the tracks. This work was financed through projects: CONAGYT-103773, "Reconstrucción Paleoclimática y Distribución de Gimnospermas en el Jurásico de Oaxaca", and PAPIIT-IN-106010-3, "Distribución de Gimnospermas en el Jurásico de la
Región Norte del Terreno Mixteco y Reconstrucción Paleoecológica"; RARR thanks Unidades Académicas de Ciencias Biológicas y Ciencias de la Tierra, Universidad Autónoma de Zacatecas for their kind support; as well as to project UAZ2015-36941 (Diversidad de Icnofósiles de Vertebrados en México: Implicaciones Paleobiológicas y Paleoecológicas).

\section{References}

Antevs, E., 1919, Die liassische flora des Hörsandsteins: Stockholm, Sweden, Kungliga Svenska Vetenskapsakademiens Handlingar, Almqvist \& Wiksell, 59(8), 1-71.

Carpenter, K., 1982, Skeletal and dermal armor reconstruction of Euoplocephalus tutus (Ornithischia: Ankylosauridae) from the Late Cretaceous Oldman Formation of Alberta: Canadian Journal of Earth Sciences, 19(4), 689-697.

Carpenter, K., 1984, Skeletal reconstruction and life restoration of Sauropelta (Ankylosauria: Nodosauridae) from the Cretaceous of North America: Canadian Journal of Earth Sciences, 21(12), 1491-1498.

Carpenter, K., Miles, C., Cloward, K., 1998, Skull of a Jurassic ankylosaur (Dinosauria): Nature, 393, 782-783.

Carrasco-Ramírez, R.S., 1981, Geología Jurásica del área de Tlaxiaco, Mixteca Alta, Oaxaca: Mexico City, Mexico, Universidad Nacional Autónoma de México, Facultad de Ciencias, MSc Thesis, 146 p.

Chinnery, B.J., Lipka, T.R., Kirkland, J.I., Parrish, J.M., Brett-Surman, M.K., 1998, Neoceratopsian teeth from the Lower to Middle Cretaceous of North America, in Lucas, S.G., Kirkland, J.I., Estep, J.W. (eds.), Lower and Middle Cretaceous Terrestrial Ecosystems: Albuquerque, New Mexico, U.S.A., New Mexico Museum of Natural History and Science Bulletin, 14, 297-302. 
Corro-Ortiz, M.G., Ruíz-González, F.J., 2011, Análisis estratigráfico de las secuencias Jurásicas del área de Tlaxiaco, Oaxaca: Mexico City, Mexico, Universidad Nacional Autónoma de México, Facultad de Ingeniería, BSc Thesis, $134 \mathrm{p}$.

Dávalos-Álvarez, O.G., 2006, Evolución tectónica cenozoica en la porción norte de la falla de Oaxaca: Juriquilla, Querétaro, Mexico, Universidad Nacional Autónoma de México, Centro de Geociencias, MSc Thesis, 132 p.

Delevoryas, T., Person, C.P., 1975, Mexiglossa varia gen. et sp. nov., a new genus of Glossopteroid leaves from the Jurassic of Oaxaca, Mexico: Palaeontographica Abteilung B, 154, 114-120.

Erben, H.K., 1956, El Jurásico Medio y el Caloviano de México (abstract), in XX Congreso Geológico Internacional: Mexico City, Mexico, Sociedad Geológica Mexicana, $11-36$.

Galton, P.M., 1983, Armored dinosaurs (Ornithischia: Ankylosauria) from the Middle and Upper Jurassic of Europe: Palaeontographica Abteilung A, 182, 1-25.

González-Torres, E.A., 1989, Geología y Paleomagnetismo del área de Tezoatlán, Oaxaca: Mexico City, Mexico, Universidad Nacional Autónoma de México, Facultad de Ingeniería, BSc Thesis, 188 p.

Haubold, H., 1971, Ichnia Amphibiorum et Reptiliorum Fossilium, in Kuhn, O. (ed.), Handbuch der Paläoherpetologie: Stuttgart, Germany, Gustav Fischer Verlag, 18, 123 p.

Hups, K., Lockley, M.G., Foster, J., Gierlinski, G., 2008, The first ankylosaur track from the Jurassic: Journal of Vertebrate Paleontology, 28, 94A.

Jack, R.L., Etheridge, R.jr., 1892, The Geology and Palaeontology of Queensland and New Guinea, with sixty-eigth plates and a Geological Map of Queensland: Queensland, Australia, James Charles Beal, Government Printer, 768 p.
Kappus, E.J., Lucas, S.G., Langford, R., 201 1, The Cerro de Cristo Rey Cretaceous dinosaur tracksites, Sundland Park, New Mexico, USA, and Chihuahua, Mexico, in Sullivan, R.M., Lucas, S.G., Spielmann, J.A. (eds.), Fossil Record 3: Albuquerque, New Mexico, U.S.A., New Mexico Museum of Natural History and Science Bulletin, 53, 272-288.

Kirkland, J.I., Carpenter, K., 1994, North America's first pre-Cretaceous ankylosaur (Dinosauria) from the Upper Jurassic Morrison Formation of Western Colorado: Brigham Young University Geology Studies, 40, 25-42.

Kirkland, J.I., Carpenter, K., Hunt, A.P., Scheetz, R.D., 1998, Ankylosaur (Dinosauria) specimens from the Upper Jurassic Morrison Formation: Modern Geology, 23, 145-177.

Leonardi, G., 1984, Le impronte fossili di dinosauri, in Bonaparte, J.F., Colbert, E.H., Currie, P., de Ricqles, A., Kielan-Jaworowska, Z., Leonardi, G., Morello, N., Taquet, P. (eds.), Sulle Orme dei Dinosauri: Venice, Italy, Errizo Editrice, 165-186.

Leonardi, G., 1994, Annotated atlas of South America tetrapod footprints (Devonian to Holocene), with an appendix of Mexico and Central America: Brasilia, Brazil, Companhia de Pesquisa de Recursos Minerais, 246 p.

Lockley, M.G., Hunt, A.P., 1995, Ceratopsid tracks and associated ichnofauna from the Laramie Formation (Upper Cretaceous: Maastrichtian) of Colorado: Journal of Vertebrate Paleontology, 15(3), 592-614.

Lockley, M.G., Meyer, C.A., Hunt, A.P., Lucas, S.G., 1994, The distribution of sauropod tracks and trackmakers: Gaia, 10, 233-248.

Lockley, M.G., Hups, K., Trujillo, K., Gerwe, D.S., 2014, Mesozoic vertebrate tracksites from the Dominguez-Escalante National Conservation Area of Western Colorado: implications for paleoecology and management, in Lockley, M.G., Lucas, S.G. (eds.), Fossil footprints of western North America: Albuquerque, New 
Mexico, U.S.A., New Mexico Museum of Natural History and Science Bulletin, 62, 215-223.

Lozano-Carmona, D.E., 2012, Paleoclima y Flora Fósil de Río Numí, Formación Zorrillo-Taberna Indiferenciada, Oaxaca: Mexico City, Mexico, Universidad Nacional Autónoma de México, Facultad de Estudios Superiores Zaragoza, BSc Thesis, 174 p.

Lozano-Carmona, D.E., Velasco-de León, M.P., 2016, Jurassic flora in Southeast Mexico: importance and prospects of recent findings in the Mixteco Terrane: Paleontología Mexicana, 5(2), 87-101.

Martínez-Díaz, J.L., Montellano-Ballesteros, M., 2011, Anquilosaurios (ThyreophoraAnkylosauria) del Cretácico Superior de México (abstract), in XII Congreso Nacional de Paleontología: Puebla, Mexico, Sociedad Mexicana de Paleontología, 93.

Mateus, O., Milàn, J., Romano, M., Whyte, M.A., 2011, New finds of stegosaur tracks from the Upper Jurassic Lourinhã Formation, Portugal: Acta Palaeontologica Polonica, 56(3), 651-658.

McGrea, R.T., Lockley, M.G., Meyer, C.A., 2001, Global distribution of purported ankylosaur track occurrences, in Carpenter, K. (ed.), The armored dinosaurs: Bloomington, Indiana, U.S.A., Indiana University Press, 413-454.

Milàn, J., Chiappe, L.M., 2009, First American Record of the Jurassic Ichnospecies Deltapodus brodricki and a Review of the Fossil Record of Stegosaurian Footprints: The Journal of Geology, 117(3), 343-348.

Nopcsa, F., 1923, Die Familien der Reptilien: Fortschritte der Geologie und Palaeontologie, 2, 1-210.

Ortiz-Martínez, E.L., Velasco-de León, M.P., Salgado-Ugarte, I., Silva-Pineda, A., 2013, Clasificación del área foliar de las gimnospermas fósiles de la zona norte de Oaxaca, México: Revista Mexicana de Ciencias Geológicas, 30(1), 150-158.
Pérez-Ibargüengoitia, J.M., Hokuto-Castillo, A., Cserna, Z.de, 1965, Estratigrafía y paleontología del Jurásico Superior de la parte centromeridional del Estado de Puebla: Paleontología Mexicana, 21, 5-22.

Person, C.P., Delevoryas, T., 1982, The middle Jurassic flora of Oaxaca Mexico: Palaeontographica Abteilung B, 180, 82-119.

Pott, C., McLoughlin, S., 2009, Bennettitalean foliage from the Rhaetian-Bajocian (latest Triassic-Middle Jurassic) floras of Scania, southern Sweden: Review of Palaeobotany and Palynology, 158, 117-166.

Rees, P.McA., Ziegler, A.M., Valdes, P.J., 2000, Jurassic phytogeography and climates: New data and model comparisons, in Huber, B.T., MacLeod, K.G., Wing, S.L. (eds.), Warm climates in Earth history: Cambridge, U.K., Cambridge University Press, 297-318.

Rivera-Sylva, H.E., Espinosa-Chávez, B., 2006, Ankylosaurid (Dinosauria: Thyrephora) osteoderms from the upper Cretaceous Cerro del Pueblo Formation of Coahuila, Mexico: Carnets de Géologie/Notebooks on Geology, 6, Letter 2.

Rivera-Sylva, H.E., Carpenter, K., ArandaManteca, F.J., 2011, Late Cretaceous nodosaurids (Ankylosauria: Ornithischia) from Mexico: Revista Mexicana de Ciencias Geológicas, 28(3), 371-378.

Rodríguez-de la Rosa, R.A., 2014, Sinopsis sobre la paleoicnología de vertebrados en México (abstract), in Reynoso-Rosales, V.H. (ed.), VIII Congreso Latinoamericano de Paleontología and XIII Congreso Nacional de Paleontología: Guanajuato, Mexico, Universidad Nacional Autónoma de México, Informe final SNIB-CONABIO LU006, 79.

Rodríguez-de la Rosa, R.A., 2015, Hace 72 millones de años: Los dinosaurios de México: Chihuahua, Mexico, Instituto Chihuahuense de Cultura, Museo del Desierto, 179 p. 
Rodríguez-de la Rosa, R.A., Velasco-de León, M.P., Lozano-Carmona, D.E., 2014, El registro de huellas de vertebrados del Jurásico de México (abstract), in Reynoso-Rosales, V.H. (ed.), VIII Congreso Latinoamericano de Paleontología and XIII Congreso Nacional de Paleontología: Guanajuato, Mexico, Universidad Nacional Autónoma de México, Informe final SNIB-CONABIO LU006, 79.

Rojas-Chávez, G., 2010, Taxonomía de Dicksoniaceae, Gleicheniaceae y Matoniaceae (Filicales) del Jurásico en la región Mixteca, México: Mexico City, Mexico, Universidad Nacional Autónoma de México, Facultad de Estudios Superiores Zaragoza, BSc Thesis, 121 p.

Sandoval, J., Westermann, G.E.G., 1986, The Bajocian (Jurassic) ammonite fauna of Oaxaca, Mexico: Journal of Paleontology, 60(6), 1220-1271.

Sedlock, R.L., Ortega-Gutiérrez, F., Speed, R.C., 1993, Tectonostratigraphic terranes and tectonic evolution of Mexico: Geological Society of America, Special Paper 278, 153 p.

Sennikov, A.G., 2006, Reading segnosaur tracks (in Russian): Priroda, 5, 58-67.

Senter, P., 2011, Evidence for a sauropod-like metacarpal configuration in ankylosaurian dinosaurs: Acta Palaeontologica Polonica, 56(1), 221-224.

Silva-Pineda, A., Velasco-de León, M.P., Rodríguez Becerra, R., 2007, Tafonomía de plantas Jurásicas de Oaxaca y Puebla, México (abstract), in III Simposio Argentino Jurásico: Mendoza, Argentina, 76.

Sternberg, C.M., 1932, Dinosaur tracks from Peace River, British Columbia: Ottawa, Canada, National Museum of Canada Annual Report for 1930, 59-85.
Van Konijnenburg-Van Cittert, J.H.A., 2002, Ecology of some Late Triassic to Early Cretaceous ferns in Eurasia: Review of Palaeobotany and Palynology, 119, 113-124.

Velasco-de León, M.P., Ortiz-Martínez, E., Silva-Pineda, A., Lozano-Carmona, D.E., 2013, Distribución y ambientes de las gimnospermas fósiles del Terreno Mixteco: Paleontología Mexicana, 63, 122-143.

Velasco-de León, M.P., Lozano-Carmona, D.E., Flores-Barragan, M.A., Martínez-Paniagua, O.D., Silva-Pineda, A., 2015, Two new species of Ginkgoales from the Middle Jurassic of Mexico: Historical Biology, An International Journal of Paleobiology, 27, 366-373.

Wang, Y., Guignard, G., Thévenard, F., Dilcher, D., Barale, G., Mosbrugger, V., Yang, X., Mei, S., 2005, Cuticular anatomy of Sphenobaiera huangii (Ginkgoales) from the Lower Jurassic of Hubei, China: American Journal of Botany, 92(4), 709-721.

Whyte, M.A., Romano, M., 1994, Probable sauropod footprints from the Middle Jurassic of Yorkshire, England, in Lockley, M.G., Dos Santos, V.F., Meyer, C.A., Hunt, A. (eds), Aspects of Sauropod Paleobiology: Gaia, 10, $15-26$

Wieland, G.R., 1914, La Flora liásica de la Mixteca Alta: Boletín del Instituto Geológico de México, 31, 1-65.

Wolfe, D.G., Kirkland, J.I., 1998, Zuniceratops christopheri n. gen. \& n. sp., a ceratopsian dinosaur from the Moreno Hill Formation (Cretaceous, Turonian) of west-central New Mexico, in Lucas, S.G., Kirkland, J.I., Estep, J.W. (eds.), Lower and Middle Cretaceous Terrestrial Ecosystems: Albuquerque, New Mexico, U.S.A., New Mexico Museum of Natural History and Science Bulletin, 14, 303-317. 
Zakharov, S.A., 1964, On the Cenomanian dinosaur, the tracks of which were found in the Shirkent River Valley, in Reiman, V.M. (ed.), Paleontology of Tadzhikistan: Dushanbe, Tajikistan, Ajadennuta Bayj Tadzhikskoi SSR, 31-35.
Zhiming, D., 1993, An ankylosaur (ornithischian dinosaur) from the Middle Jurassic of the Junggar Basin, China: Vertebrata PalAsiatica, 10, 257-266.

Zhou, Z-.Y., 2009, An overview of fossil Ginkgoales: Palaeoworld, 18(1), 1-22. 